\title{
Effect of calorie intake on nitrogen retention in the immature fowl
}

\author{
BY W. R. SANSLONE AND R. L. SQUIBB \\ Laboratories of Disease and Environmental Stress, Rutgers, \\ The State University, New Brunswick, New fersey \\ (Received 2 December 1962-Revised 25 March 1963)
}

Munro (1951) showed that nitrogen retention in rats is reduced when calorie intake is restricted. Although an adaptive process to continued moderate calorie restriction was demonstrated with dogs (Rosenthal \& Allison, 195I) and man (Drury, Vaughan \& Hannon, 1959), a linear relationship between $\mathrm{N}$ balance and the amount of carbohydrate given along with the protein of the diet was observed in rats (Thomson \& Munro, 1955).

The sparing effect of dietary fat on $\mathrm{N}$ has been demonstrated with rats by Cohn $\&$ Joseph (1956) and Schreiber \& Elvehjem (1955), with dogs by Ontko, Wuthier \& Phillips (1957) and with man by Swift et al. (1959).

Rand, Scott \& Kummerow (1958) substituted maize oil isocalorically for glucose and reported improvement in growth and protein retention as measured by carcass analysis of representative chicks.

In our laboratories we are interested in the effect of calorie intake of other than nitrogenous origin on $\mathrm{N}$ retention in the fowl. Earlier studies on the effect of diet on Newcastle-disease virus (NDv) infection in chicks (Squibb, 1961) showed that nutrient intake was significantly lower during the active involvement stage of the disease. Sanslone \& Squibb $(1962 b)$ later demonstrated that $\mathrm{N}$ balance was severely depressed during the course of NDV infection. The extent to which NDV influenced the depression was related to the virulence of the infection, which in turn affected dietary $\mathrm{N}$ intake.

In the trials reported here, $N$ retention was measured in chicks given a wide range of calorie intake, wherein calories of protein origin were held constant but those from other than protein sources were varied.

\section{EXPERIMENTAL}

\section{Procedure}

The effect of different levels of calorie intake on $\mathrm{N}$ balance in the immature fowl was observed in a series of eight trials.

So that protein and other nutrients could be held constant and yet calorie intake adjusted from 50 to $150 \%$ of normal, two separate diets were employed, diet I for calorie restriction (trials $1-4$ ) and diet 2 for surfeit calorie feeding (trials 5-8). The composition of these diets is given in Table $\mathrm{I}$.

In each trial some sixty day-old White Leghorn cockerels of known breeding were 
used initially. For trials $1-4$ the chicks were given diet 1 ad lib. and in trials $5-8$ diet 2 was supplied for a preliminary 6-day period. The birds were weighed at intervals and the weights were used to match five pairs of chicks which were then placed in individual metabolism cages (Sanslone \& Squibb, 196I); the remaining birds were discarded. The cages were maintained in an air-conditioned room kept at $75^{\circ} \mathrm{F}$. Water was provided ad lib.

\section{Table I. Percentage composition of experimental diets}

\begin{tabular}{lrc}
\multicolumn{1}{c}{ Ingredient } & Diet I & Diet 2 \\
Maize oil* & 20.40 & - \\
Solka floct & $18 \cdot 40$ & - \\
Maize meal & $17 \cdot 15$ & 55.90 \\
Soya-bean meal & 33.50 & 34.00 \\
Lucerne & 2.60 & 3.00 \\
Corn distillers' solubles & $4 \cdot 00$ & 4.00 \\
Dicalcium phosphate & $1 \cdot 70$ & 2.20 \\
Calcium carbonate & $1 \cdot 00$ & - \\
Salt & 0.50 & 0.50 \\
Mineral concentrate $f$ & 0.10 & 0.10 \\
DL-methionine & 0.25 & - \\
Arginine & 0.10 & - \\
Vitamin premix $\$$ & 0.30 & 0.30 \\
& 100.00 & 100.00 \\
Protein, by analysis (\%) & 20.02 & 20.97 \\
Productive energy (kcal/lb) & 856 & 845 \\
Productive energy from maize & 428 & - \\
oil (kcal/lb) & &
\end{tabular}

- 20.40, $10 \cdot 20,5 \cdot 10$ and $2 \cdot 55$ parts maize oil omitted from diets prepared for pair-fed animals in trials $I, 2,3$ and 4 , respectively.

+ A fibre filler (ground wood pulp) of little nutritional value.

$\$$ Containing $\mathrm{Mn} \mathrm{I} \cdot 7, \mathrm{I} 0.06, \mathrm{Fe} 0.175, \mathrm{Zn} 1 \cdot 0, \mathrm{Co} 0.01$ and $\mathrm{Ca} 32.0 \%$.

§ Containing per $1 \mathrm{~b}$ : 1000000 i.u. vitamin $\mathrm{A}, 250000$ i.u. vitamin $\mathrm{D}_{3}, 500 \mathrm{mg}$ riboflavin, $1000 \mathrm{mg}$ calcium pantothenate, $2000 \mathrm{mg}$ nicotinic acid, $50 \mathrm{mg}$ choline chloride and $1 \mathrm{mg}$ vitamin $\mathrm{B}_{12}$.

Balance periods varied from 4 to 7 days; the specific periods and calorie levels provided for each trial were as shown in Table 3. A $24 \mathrm{~h}$ equilibration period was allowed before daily collection of faeces began. After this period the $24 \mathrm{~h}$ excreta from each bird were scraped into I l. glass jars containing $100 \mathrm{ml}$ distilled water. The samples were homogenized and diluted with water to $250 \mathrm{ml}$. Duplicate $3 \mathrm{ml}$ portions were analysed for $\mathrm{N}$ by the micro-Kjeldahl procedure (Association of Official Agricultural Chemists, 1955).

An estimate of $\mathrm{N}$ loss was believed to be of value. Therefore, in the first four trials $\mathrm{N}$ retention was also determined by carcass analysis. These values, when compared with $\mathrm{N}$ retention values obtained by the usual $\mathrm{N}$ balance methods, indicated differences to be less than $5 \%$. Details of the analytical and calculation methods used have been reported previously by Sanslone \& Squibb (1962a). All values were treated by statistical procedures according to Snedecor (1956), designed to measure variation over the entire period, and also by $t$ tests between the control and pair-fed chicks. 


\section{Calorie restriction}

During the balance studies the control chicks of trials I-4 received diet I (Table I) ad lib. The calorie intake of the pair-fed chicks was restricted to $50,75,88$ and $94 \%$ of normal by omitting varying quantities of the maize oil in diet $\mathrm{I}$ and adjusting their daily food intake so that they would receive the same quantity of protein, minerals and other dietary essentials as the controls given diet $\mathrm{I} a d l i b$. and without restriction of calories.

Table 2. Final body-weights $(g)$ of control and pair-fed chicks on various restricted and surfeit calorie regimens

\begin{tabular}{|c|c|c|c|c|c|c|c|c|c|c|c|c|c|c|c|c|}
\hline \multirow{3}{*}{$\begin{array}{c}\text { Block } \\
\text { no. }\end{array}$} & \multicolumn{16}{|c|}{ Trial no. } \\
\hline & \multicolumn{2}{|c|}{$I(50)$} & \multicolumn{2}{|c|}{$2(75)$} & \multicolumn{2}{|c|}{$3(88)$} & \multicolumn{2}{|c|}{$4(94)$} & \multicolumn{2}{|c|}{$5(106)$} & \multicolumn{2}{|c|}{$6(112)$} & \multicolumn{2}{|c|}{$7(125)$} & \multicolumn{2}{|c|}{$8(150) \dagger$} \\
\hline & C & PF & C & PF & C & $\mathrm{PF}$ & $\mathrm{C}$ & $\mathrm{PF}$ & C & PF & $\mathrm{C}$ & $\mathrm{PF}$ & C & PF & C & PF \\
\hline I & 152 & 122 & 126 & I I I & I 58 & 146 & 181 & 164 & 145 & 145 & I 89 & 197 & I 37 & 152 & 167 & 173 \\
\hline 2 & 164 & 129 & 145 & $\times 28$ & 155 & 140 & 182 & 162 & 152 & 148 & I 98 & 185 & 168 & 146 & $15 i$ & 151 \\
\hline 3 & 159 & 127 & 144 & I3I & 162 & I5I & 203 & 190 & 143 & I55 & $18 \mathrm{I}$ & 157 & 161 & 147 & 161 & 161 \\
\hline 4 & 149 & 114 & 140 & 118 & 141 & 123 & 207 & 191 & 141 & 161 & 173 & 171 & 160 & 165 & 158 & 138 \\
\hline 5 & 163 & II 5 & $13^{8}$ & 117 & 170 & 161 & 190 & 177 & 164 & $15^{8}$ & 197 & 190 & 149 & 151 & 179 & 176 \\
\hline Mean & 157 & 121 & I 39 & 121 & 157 & 144 & 193 & 177 & 149 & 153 & 188 & 180 & 155 & 152 & 163 & 160 \\
\hline$P$ valu & $<$ & D.0I & $<$ & 01 & $<$ & .01 & $<$ & & & & & & & & & \\
\hline
\end{tabular}

C, control group; PF, pair-fed group.

- Figures in parentheses show the calorie intake as a percentage of normal.

$\dagger$ See p. 462 .

Table 3. Mean values with their standard errors for nitrogen retained daily $(\mathrm{mg})$ by control and pair-fed chicks during restricted and surfeit calorie feeding

Calorie

level for PF chicks

Trial (\% of

no. control)

50

(1)

Nitrogen retained

\begin{tabular}{|c|c|c|c|c|c|c|c|c|c|}
\hline 1 & 50 & $\begin{array}{l}\mathrm{C} \\
\mathrm{PF}\end{array}$ & $\begin{array}{l}2 I I \pm 35 \\
276 \pm 27^{* 0}\end{array}$ & $\begin{array}{l}290 \pm 31 \\
102 \pm 28^{* 0}\end{array}$ & $\begin{array}{r}307 \pm 27 \\
75 \pm 44\end{array}$ & $\begin{array}{r}352 \pm 44 \\
54 \pm 30\end{array}$ & - & - & - \\
\hline 2 & 75 & $\begin{array}{l}\mathrm{C} \\
\mathrm{PF}\end{array}$ & $\begin{array}{l}278 \pm 20 \\
221 \pm 32 * *\end{array}$ & $\begin{array}{l}239 \pm 39 \\
244 \pm 33\end{array}$ & $\begin{array}{l}282 \pm 34 \\
186 \pm 4 \mathrm{I}\end{array}$ & $\begin{array}{l}294 \pm 35 \\
206 \pm 40^{\circ}\end{array}$ & - & - & - \\
\hline 3 & 88 & $\begin{array}{l}\mathrm{C} \\
\mathrm{PF}\end{array}$ & $\begin{array}{l}191 \pm 47 \\
215 \pm 11\end{array}$ & $\begin{array}{l}177 \pm 71 \\
173 \pm 36\end{array}$ & $\begin{array}{l}255 \pm 35 \\
211 \pm 33^{\circ}\end{array}$ & $\begin{array}{l}23 I \pm 3 I \\
23 I \pm 50\end{array}$ & $\begin{array}{l}294 \pm 25 \\
243 \pm 34^{\circ}\end{array}$ & $\begin{array}{l}316 \pm 35 \\
256 \pm 51\end{array}$ & $\begin{array}{l}341 \pm 65 \\
302 \pm 65\end{array}$ \\
\hline 4 & 94 & $\begin{array}{l}\text { C } \\
\text { PF }\end{array}$ & $\begin{array}{l}275 \pm 11 \\
309 \pm 35\end{array}$ & $\begin{array}{l}285 \pm 61 \\
294 \pm 34\end{array}$ & $\begin{array}{l}314 \pm 20 \\
293 \pm 54\end{array}$ & $\begin{array}{l}342 \pm 26 \\
298 \pm 27\end{array}$ & $\begin{array}{l}394 \pm 12 \\
310 \pm 39\end{array}$ & $\begin{array}{l}433 \pm 35 \\
369 \pm 3^{8}\end{array}$ & $\begin{array}{l}443 \pm 55 \\
415 \pm 44\end{array}$ \\
\hline 5 & 106 & $\begin{array}{l}\mathrm{C} \\
\mathrm{PF}\end{array}$ & $\begin{array}{l}228 \pm 76 \\
209 \pm 56\end{array}$ & $\begin{array}{l}207 \pm 76 \\
232 \pm 29\end{array}$ & $\begin{array}{l}249 \pm 73 \\
290 \pm 18\end{array}$ & $\begin{array}{l}241 \pm 33 \\
292 \pm 50\end{array}$ & - & - & - \\
\hline 6 & 112 & $\begin{array}{l}\text { C } \\
\text { PF }\end{array}$ & $\begin{array}{l}152 \pm 40 \\
\times 26 \pm 52\end{array}$ & $\begin{array}{l}126 \pm 47 \\
102 \pm 21\end{array}$ & $\begin{array}{l}198 \pm 39 \\
158 \pm 54\end{array}$ & $\begin{array}{l}170 \pm 43 \\
\text { r } 53 \pm 24\end{array}$ & $\begin{array}{l}234 \pm 53 \\
182 \pm 76^{\circ}\end{array}$ & $\begin{array}{l}230 \pm 52 \\
227 \pm 26\end{array}$ & $\begin{array}{l}190 \pm 50 \\
244 \pm 31\end{array}$ \\
\hline 7 & 125 & $\begin{array}{l}\mathrm{C} \\
\mathrm{PF}\end{array}$ & $\begin{array}{l}138 \pm 13 \\
152 \pm 12\end{array}$ & $\begin{array}{l}139 \pm 84 \\
60 \pm 51 *\end{array}$ & $\begin{array}{l}196 \pm 77 \\
178 \pm 62\end{array}$ & $\begin{array}{l}196 \pm 75 \\
\text { I } 71 \pm 38\end{array}$ & $\begin{array}{l}213 \pm 73 \\
256 \pm 30\end{array}$ & - & - \\
\hline 8 & 150 & $\begin{array}{l}\mathrm{C} \\
\mathrm{PF}\end{array}$ & $\begin{array}{l}196 \pm 17 \\
173 \pm 31\end{array}$ & $\begin{array}{l}292 \pm 13 \\
\text { r } 3^{8} \pm 72^{* * *}\end{array}$ & $\begin{array}{l}265 \pm 35 \\
139 \pm 27\end{array}$ & $\begin{array}{l}354 \pm 48 \\
200 \pm 24\end{array}$ & $\begin{array}{l}383 \pm 95 \\
167 \pm 81\end{array}$ & - & - \\
\hline
\end{tabular}

C, control group; PF, pair-fed group.

- Differences between control and pair-fed groups significant at $P<0.05$.

* Differences between control and pair-fed groups significant at $P<0.01$. 
Calorie excess

In trials $5-8$, control and pair-fed chicks alike received diet 2 (Table 1 ) during the balance periods. For the pair-fed chicks, calorie intake was increased to 106, 112, 125 and $150 \%$ of the controls' ad lib. intake by daily administration of maize oil at six equal time-intervals between $7.00 \mathrm{a} . \mathrm{m}$. and I 1.00 p.m. through a tube inserted into the crop of the bird. The amount of maize oil administered to the pair-fed chicks was based on the previous day's calorie consumption of the controls.

\section{RESULTS}

Table 2 shows the individual body-weights of the birds in the eight trials. Weight gains were significantly reduced when the calorie intake was restricted (trials $\mathrm{I}-4$ ). In trials 5-8 there were no significant differences in weight gains between the controls and the birds given surfeit calories.

Values presented in Table 3 show the quantity of $\mathrm{N}$ retained daily by the pair-fed groups in trials $\mathrm{I}-8$. It can be seen that on the Ist day in trial I and after the 2nd day in trial 2 there was a significant depression of $\mathrm{N}$ retention when calorie intake was restricted to 50 or $75 \%$ of normal (trials I and 2). A significant depression of $\mathrm{N}$ retention did not occur until the 3 rd day with the chicks restricted to $88 \%$. With the chicks given $94 \%$ of normal calorie intake, $\mathrm{N}$ retention was affected significantly on the $5^{\text {th }}$ and 6 th days.

No consistent differences in $\mathrm{N}$ retention were noted in trials 5, 6 and 7 when calorie intake was increased to 106, I I 2 and $125 \%$ of normal. However, in trial 8 , when calorie intake was increased to $150 \%$ of normal the excessive quantities of maize oil reduced the ad lib. consumption of the normal diet which in turn reduced $\mathrm{N}$ intake approximately $38 \%$. Under these conditions the significant depression of $\mathrm{N}$ retention observed on the 2nd day of the balance period continued to the end of the trial. Within the timeintervals studied, $\mathrm{N}$ retention tended to increase linearly ( 1 ) with age in the control birds and in those pair-fed chicks given 88, 94, I06, I 12 and I $25 \%$ of the normal calorie intake; and (2) with body-weight in the control groups.

\section{DISCUSSION}

In these trials the effect of restricted and surfeit calorie feeding on $\mathrm{N}$ balance was studied during the stage of rapid growth of the chick. Lower weight gains of the chicks on the restricted calorie regimen were to be expected. Surfeit calorie feeding within the time-intervals studied had no effect on weight gains. In trial 8 when $150 \%$ of the calorie intake of the controls was supplied to the pair-fed chicks, feed consumption was less and thus $\mathrm{N}$ intake was reduced by $38 \%$. The reduced $\mathrm{N}$ intake explains the depressed $\mathrm{N}$ retention observed in this group. The lack of effect on weight gains in the chicks given $150 \%$ of the normal calorie intake was no doubt due to fat replacing protein as an energy source.

With $\mathrm{N}$ intake constant, the restriction of calories of other than nitrogenous origin over the range of $50-94 \%$ of the controls had a greater effect on depressing $\mathrm{N}$ balance 
than did the excess calories provided by supplementary maize oil. With restricted calorie feeding, protein presumably replaced fat as an energy source.

From the results presented it is evident that in chicks the effect of calorie intake on $\mathrm{N}$ balance is not linear. Further, there was a good deal of variation in $\mathrm{N}$ retention between days on balance in the groups given $88-125 \%$ of the normal calorie intake. This variability may be attributed in part to an attempt by the bird to adjust to the varying calorie intake. The apparent adaptive process observed in the groups given 88 and $94 \%$ of the normal calorie intake would indicate that the chick as well as the $\operatorname{dog}$ (Rosenthal \& Allison, 195I) and man (Drury et al. 1959) has the ability to adjust to moderate calorie restriction.

\section{SUMMARY}

I. Eight nitrogen balance trials were conducted with White Leghorn cockerel chicks given diets which provided a constant intake of $\mathrm{N}$ but with calorie intakes adjusted to $50-150 \%$ of normal.

2. Body-weights were significantly depressed in the birds limited to $50,75,88$ and $94 \%$ of normal calorie intake; no adverse effect was observed in chicks given ro6-1 $50 \%$ of normal, but at the last level of intake some of the basal diet remained uneaten.

3. With protein intake constant, calorie restriction had greater effect than calorie excess in depressing $\mathrm{N}$ balance in the chick.

4. An apparent adaptive process to continued moderate calorie restriction is believed to exist in the chick as well as in the dog and man.

We wish to thank Miss Portia Burt for her technical assistance and Miss Marie Utzinger for assisting in the preparation of the manuscript.

The work was supported in part by U.S. Public Health Service Grant E-3645 and the Grange League Federation, Ithaca, N.Y.

\section{REFERENCES}

Association of Official Agricultural Chemists (1955). Official Methods of Analysis, 8th ed. Washington: Association of Official Agricultural Chemists.

Cohn, C. \& Joseph, D. (1956). Proc. Soc. exp. Biol., N.Y., 93, 462.

Drury, H. F., Vaughan, D. A. \& Hannon, J. P. (1959). F. Nutr. 67, 85.

Munro, H. N. (1951). Physiol. Rev. 3r, 449.

Ontko, J. A., Wuthier, R. E. \& Phillips, P. H. (1957). I. Nutr. 62, 163.

Rand, N. T., Scott, H. M. \& Kummerow, F. A. (1958). Poult. Sci. 37, 1075.

Rosenthal, H. L. \& Allison, J. B. (1951). J. Nutr. 44, 423.

Sanslone, W. R. \& Squibb, R. L. (1961). Poult. Sci. 40, 816.

Sanslone, W. R. \& Squibb, R. L. (1962a). Brit. F. Nutr. 16, 59.

Sanslone, W. R. \& Squibb, R. L. (1962b). Y. Nutr. 76, 86.

Schreiber, M. \& Elvehjem, C. A. (1955). $\mathcal{~ F . ~ N u t r . ~ 5 7 , ~} 133$.

Snedecor, G. W. (1956). Statistical Methods, 5th ed., Ames, Iowa: Iowa State University Press.

Squibb, R. L. (1961). Poult. Sci. 40, 425.

Swift, R. W., Barron, G. P., Fisher, K. H., Cowan, R. L., Hartsook, E. W., Hershberger, T. V., Keck, E., King, R. P., Long, T. A. \& Berry, M. E. (1959). Э. Nutr. 68, 28 r.

Thomson, W. S. T. \& Munro, H. N. (2955). $₹$. Nutr. 56, 139. 